\title{
STATUS PEKERJAAN IBU DAN STATUS GIZI (IMT/U DAN TB/U) ANAK PRA-SEKOLAH KOTA MATARAM
}

\author{
Endy Bebasari Ardhana Putri ${ }^{1}$, Humaediah Lestari ${ }^{2}$ \\ ${ }^{1,2)}$ Sekolah Tinggi Ilmu Kesehatan (STIKES) Mataram \\ Email : bebasari_putri@yahoo.com
}

\begin{abstract}
ABSTRAK
Data Riskesdas tahun 2018 menunjukkan bahwa angka stunting anak balita di Indonesia masih $30.8 \%$, masih di bawah standar WHO untuk suatu Negara. Status gizi anak pra sekolah (4-6 tahun) dapat mempengaruhi tumbuh kembangnya. Ada beberapa faktor yang berhubungan dengan status gizi antara lain pekerjaan ibu yang secara tidak langsung mempengaruhi waktu pola asuh. Tujuan penelitian ini adalah untuk mengetahui ada tidaknya hubungan pekerjaan ibu dengan status gizi anak prasekolah di RA al-Fath.

Status gizi yang diukur berdasarkan indikator Indeks Massa Tubuh (IMT) menurut umur dan tinggi badan menurut umur. Sampel diambil dengan total sampling dari seluruh siswa-siswi di RA-Al-Fath yang berada di kelurahan Karang Pule Sekarbela yang berjumlah 38 anak. Rancangan studi yang dgunakan adalah cross sectional. Uji analisa data menggunakan uji Chi square dengan tingkat kesalahan 5\%.

Dari penelitian yang dilakukan, ditunjukkan bahwa status gizi anak prasekolah di RA Al-Fath menurut IMT berdasarkan umur sebagian besar anak prasekolah memiliki status gizi normal (55\%), namun masih terdapat malnutrisi meliputi gizi kurang $(6 \%)$ dan obesitas (16\%), sedangkan status gizi anak prasekolah berdasarkan tinggi badan menurut umur sebagian besar memiliki tinggi badan normal (66\%), dan masih ada yang mengalami timggi badan kurang (24\%).

Kesimpulan penelitian ini adalah lebih dari 50\% anak prasekolah memiliki status gizi yang normal dan tidak ada hubungan antara pekerjaan ibu dengan status gizi anak pra sekolah baik secara IMT maupun Tinggi badan ( $p>0.05)$. Mengingat masih adanya mal nutrisi pada anak pra sekolah baik menurut IMT/U maupun TB/U, maka perlu intervensi dari pihak tenaga kesehatan setempat untuk menanggulangi malnutrisi pada anak pra sekolah dan tidak hanya fokus pada peningkatan berat badan anak, melainkan juga membantu anak memiliki status gizi yang normal.
\end{abstract}

Kata Kunci: Pekerjaan ibu, status gizi, anak prasekolah, tinggi badan, IMT

\section{MOTHER'S WORKING STATUS AND NUTRITIONAL STATUS OF PRESCHOOL CHILDREN IN MATARAM CITY}

\begin{abstract}
Riskesdas data for 2018 shows that the stunting rate for children under five in Indonesia is still 30.8\%, still below the WHO standard for a country. The nutritional status of pre-school children (4-6 years) can affect their growth and development. There are several factors related to nutritional status, including the work of the mother, which indirectly affects the time of parenting. The purpose of this study was to determine whether there is a relationship between mother's occupation and the nutritional status of preschool children in RA al-Fath.
\end{abstract}


Nutritional status as measured by the Body Mass Index (BMI) indicator by age and height by age. Samples were taken with a total sampling of all students in RA-AlFath in the Karang Pule Sekarbela village, which amounted to 38 children. The study design used was cross sectional. Data analysis test uses Chi square test with an error rate of $5 \%$.

From the research conducted, it was shown that the nutritional status of preschool children in RA Al-Fath according to BMI based on age, most preschool children have normal nutritional status (55\%), but there are still malnutrition including undernutrition (6\%) and obesity (16\%) meanwhile the nutritional status of preschool children based on height by age mostly had normal height (66\%), and there were still those who experienced underweight (24\%).

The conclusion of this study is that more than 50\% of preschool children have normal nutritional status and there is no relationship between maternal work and the nutritional status of pre-school children both in BMI and Height ( $p>0.05)$. Considering that, there is still malnutrition in preschool children according to BMI / U and Height based age, it is necessary to intervene from the local health workers to tackle malnutrition in pre-school children and not only focus on increasing the child's weight, but also helping children have status normal nutrition.

Keywords: Mother's work, nutritional, preschool children, height, BMI

\section{PENDAHULUAN}

Status gizi anak pra sekolah (4-6 tahun) dapat mempengaruhi tumbuh kembang dan status kesehatannya. Dalam masa ini, kebutuhan gizi akan protein dan lemak lebih tinggi dari masa sebelumnya ketika kelompok umur bayi dan batita (1-3 tahun). Data Riskesdas tahun 2018 menunjukkan bahwa angka stunting anak balita di Indonesia masih $30.8 \%$, masih di bawah standar WHO untuk suatu Negara (Novianto, 2019).

Dalam penelitian tahun 2019 pada anak prasekolah di suatu kecamatan kota Mataram, sudah terdeteksi bahwa terdapat hampir setengah (49\%) anak pra-sekolah tersebut tidak memiliki status gizi yang normal dilihat dari Indeks Massa Tubuh (IMT). IMT menunjukkan status gizi dari bentuk keproporsionalan tubuh yang diukur dari berat badan dan tinggi badan yang disesuaikan umur dan jenis kelamin anak.

Ada berbagai faktor yang menyebabkan status gizi anak prasekolah yang tidak normal. Salah satunya adalah faktor ibu, mulai dari pekerjaan yang mempengaruhi waktu asuh, pendidikan serta pengetahuan, budaya, dan sebagainya. Faktor tidak langsung tersebut mempengaruhi pola asuh termasuk pemberian asupan makanan yang berkaitan dengan status gizi anak prasekolah.

Status gizi tidak normal pada anak pra-sekolah meliputi berat badan kurang, berat badan lebih atau obesitas, dan tinggi badan kurang. Status gizi yang tidak normal dapat menyebabkan gangguan pertumbuhan anak pra-sekolah dan tidak selalu dialami oleh anak dari orang tua berpendidikan rendah. Pada penelitian di kota Padang, 35\% anak usia baru masuk sekolah dasar yang mengalami stunting (tinggi badan rendah) memiliki ibu yang berpendidikan tingi (Sulastri, 2012). Faktor ibu dapat mempengaruhi status gizi anak dapat dilihat pada salah satu penelitian Di Kabupaten Klaten yang menunjukkan bahwa ada hubungan pekerjaan ibu dengan status gizi anak balita $(p=0.001)$. Anak balita adalah umur 
0 sampai 5 tahun yang termasuk di dalamnya anak prasekolah (Nisak, 2018).

Salah satu upaya menjaga status gizi anak pra sekolah tetap normal adalah dengan memonitor status gizinya setiap bulan. Status gizi dapat diukur dari Indek Massa Tubuh (IMT) yang didasarkan pada umur anak tersebut. IMT menggambarkan bentuk fisik tubuh anak sesuai umurnya, sehingga dapat dilihat kurang lebihnya berat badan dan tinggi badannya (Supariasa dkk, 2016). Selain itu, IMT juga mengukur tinggi badan anak prasekolah sehingga data yang dihasilkan dapat untuk dijadikan monitor anak dalam pencegahan stunting.

Oleh karenanya, peneliti tertarik melakukan penelitian ini dengan tujuan untuk mengetahui hubungan pekerjaan ibu dengan status gizi anak prasekolah di salah satu Sekolah PAUD Kota Mataram secara antropometri dari parameter IMT dan tinggi badan.

\section{BAHAN DAN METODE}

Populasi dari penelitian ini adalah seluruh anak prasekolah (murid TK A dan TK B) yang ada di RA Al-Fath dengan sampel berjumlah 38 anak. Teknik sampling yang dipilih adalah total sampling dengan kriteria pemilihan berumur 4-6 tahun.

Penelitian yang merupakan deskriptif observasional ini memiliki rancangan penelitian cross sectional. Pengambilan data dilakukan pada bulan November tahun 2019 di RA AlFath kecamatan Sekarbela Kota Mataram. Penelitian ini menggunakan uji korelasi non parametrik dengan alat bantu program SPSS 16. Uji statistiknya merupakan Chi Square dengan $\alpha=0.05$. Variabel independen yang diukur yaitu status gizi anak prasekolah IMT menurut umur dan Tinggi badan menurut umur, sedangkan variabel independennya yaitu pekerjaan ibu. Waktu penelitian dilakukan selama bulan November - Desember tahun 2019 di RA Al-Fath. Instrumen yang digunakan adalah mikrotoise, alat timbang badan digital, lembar standar grafik Body Mass Index dari CDC 2000 (Center of promotion health and disease prevention). Rumus IMT = BB/TB2 .

\section{HASIL DAN BAHASAN}

\section{a. Umur dan Jenis Kelamin}

Karakteristik sampel menurut umur dapat dilihat pada gambar di bawah ini:

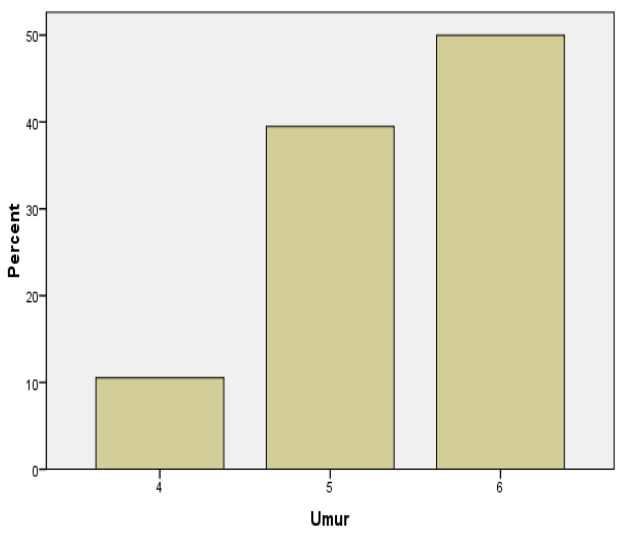

Gbr. 1. Grafik Persentase Jumlah Anak menurut Umur

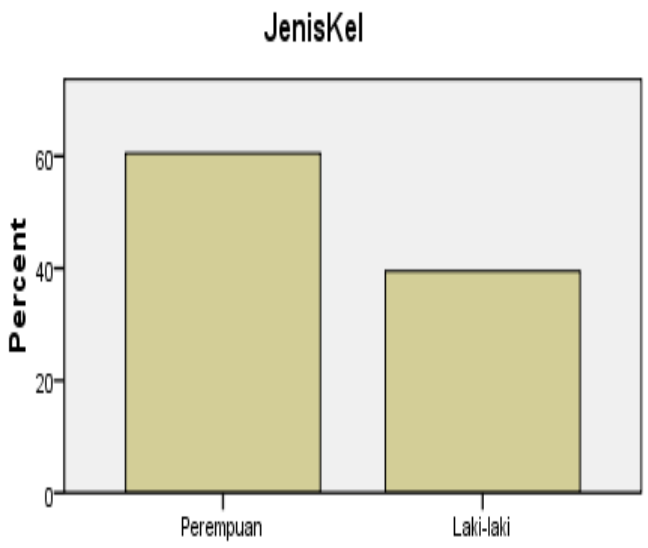

Gbr. 2. Grafik Persentase Anak menurut Jenis Kelamin

Gambar 1 menunjukkan bahwa sebagian besar anak pra sekolah di RA Al-Fath berumur 6 tahun. Paling sedikit berumur 4 tahun (10\%). Hal ini dapat dikatakan usia tersebut sudah tepat berada di sekolah TK dan sederajat. Kelompok umur pra sekolah terdapat pada kurun umur antara $3-6$ tahun (Adriani dan Wirjatmadi, 2012). Pada 
kelompok umur ini anak sudah tertarik mengikuti gerakan orang dewasa sehingga bisa diberikan pendidikan cara hidup sehat. Oleh karena aktivitas yang semakin banyak diiringi pertumbuhan dan perkembangannya, maka kebutuhan gizinya akan semakin meningkat pula (Soetjiningsih, 2008). Dari grafik pada gambar kedua, jenis kelamin yang terbanyak anak pra sekolah di RA Al-fath Karang Pule adalah anak perempuan (60\%).

\section{b. Status Gizi (IMT/U) dengan Pekerjaan Ibu}

Status gizi anak pra-sekolah RA Al-fath diukur dengan dua indicator, yaitu Indeks Massa Tubuh berdasarkan umur (IMT/U) dan Tinggi Badan menurut Umur (TB/U). Dalam perhitungan IMT/U, status gizi dikategorikan dalam 4 kategori berdasarkan grafik standar BMI umur 2 sampai 18 tahun dari CDC, yaitu obesitas, gizi lebih, normal dan kurang gizi.

Hasil nilai status gizi anak prasekolah (IMT/U) berdasarkan pekerjaan ibu dapat dilihat pada tabel di bawah ini:

Tabel 1. Distribusi Status Gizi (IMT/U) Anak Prasekolah RA AlFath berdasarkan Pekerjaan Ibu Tahun 2019

\begin{tabular}{|l|l|l|c|c|c|c|c|c|c|c|c|}
\hline & \multicolumn{7}{|c|}{ Status Gizi (IMT/U) } & \multicolumn{3}{|c|}{ Total } \\
\hline Pekerjaan Ibu & Obesitas & \multicolumn{2}{|c|}{$\begin{array}{c}\text { Gizi } \\
\text { Lebih }\end{array}$} & $\begin{array}{c}\text { Gizi } \\
\text { Normal }\end{array}$ & \multicolumn{2}{c|}{$\begin{array}{c}\text { Gizi } \\
\text { Kurang }\end{array}$} & \multicolumn{3}{|c|}{} \\
\cline { 2 - 13 } & $\mathrm{n}$ & $\%$ & $\mathrm{~N}$ & $\%$ & $\mathrm{n}$ & $\%$ & $\mathrm{n}$ & $\%$ & $\mathrm{n}$ & $\%$ \\
\hline IRT & 3 & 8 & 4 & 11 & 12 & 32 & 1 & 3 & 20 & 52 \\
\hline $\begin{array}{l}\text { Pedagang- } \\
\text { Wirausaha }\end{array}$ & 2 & 5 & 3 & 8 & 4 & 10 & 0 & 0 & 9 & 24 \\
\hline Pegawai & 1 & 3 & 2 & 5 & 5 & 13 & 1 & 3 & 9 & 24 \\
\hline Total & 6 & 16 & 9 & 24 & 21 & 55 & 2 & 6 & 38 & 100 \\
\hline
\end{tabular}

Sumber: data primer

Dari tabel 1 dapat dilihat bahwa sebagian besar anak prasekolah dengan kategori status gizi normal sebanyak 21 orang (55\%), dan paling sedikit dengan kategori gizi kurang sebanyak 2 orang
(6\%). Gizi lebih dan obesitas dialami juga hampir separuh siswa RA Al-Fath yaitu sebesar 40\%. Hal ini menunjukkan bahwa anak pra sekolah saat ini memiliki resiko penyakit yang berbeda dari masa sebelumnya saat anak menderita gizi kurang. Status gizi yang tidak normal dapat menyebabkan penyimpangan/masalah pada perkembangan anak (Noordiati, 2018). Kelebihan gizi anak pra sekolah akan memberikan dampak bagi kesehatan anak pada umur selanjutnya bahkan sampai dewasa kelak. Dampak buruk obesitas pada anak-anak diantaranya adalah obesitas dapat berlanjut hingga dewasa, pertumbuhan anak terganggu, dapat menyebabkan gangguan psikologis, daya tahan tubuh menurun, perubahan sendi, gangguan pernafasan, prestasi akademis terganggu, hingga berbagai penyakit tidak menular seperti penyakit jantung dan pembuluh darah, dan diabetes (Kemenkes RI, 2018).

Hampir separuh ibu dari anak prasekolah di RA Al-Fath memiliki pekerjaan di luar rumah (48\%). Pola asuh terutama dari faktor ibu sangat menentukan status gizi anak. Seiring dengan banyaknya wanita yang bekerja diluar rumah pengasuhan terkadang dilakukan oleh orang lain seperti menyewa pengasuh atau nenek. Akibatnya, tidak dapat dipastikan apakah makanan yang dikonsumsi anak seimbang atau tidak. Faktor pekerjaan ibu secara tidak langsung dapat mempengaruhi status gizi anak melalui pola makannya.

Status gizi anak prasekolah menurut Indeks Masa Tubuh (IMT) juga menggambarkan pertumbuhannya. Zat gizi untuk pertumbuhan anak adalah protein, kalsium, zat besi, zinc, dan mineral lain (Almatsier, 2012). Pemenuhan gizi yang cukup sesuai kebutuhan anak akan menyokong pertumbuhan anak menjadi optimal. Pola makan anak prasekolah masih 
dalam tahap pengenalan makanan keluarga. Selera makan anak prasekolah bergantung pada bentuk, warna, dan rasa.

Dari analisis statistik menggunakan uji Chi Square dengan $\alpha=0.05$, diperoleh nilai $p=0.903$ sehingga dapat dinyatakan bahwa tidak terdapat hubungan antara pekerjaan ibu dengan status gizi anak prasekolah RA Al-Fath. Kemungkinan selain dari faktor pekerjaan ibu, ada faktor lain yang mempengaruhi status gizi anak, yaitu faktor genetik, adanya penyakit infeksi, pendapatan keluarga, dan asupan makanan. Dari observasi lapangan, seluruh anak prasekolah di RA Al-Fath membawa bekal makanan yang mengandung gizi seperti nasi sayur dan lauk, buah, roti, dan sebagainya.

\section{c. Status Gizi (TB /U) dengan Pekerjaan Ibu}

Masalah stunting merupakan salah satu masalah gizi pada anak prasekolah di setiap negara berkembang. Pada RA Al-Fath, sebagian besar siswanya memiliki status tinggi badan normal (66\%) dimana diantaranya terbanyak berasal dari ibu sebagai ibu rumah tangga (34\%). Hal ini terjadi dikarenakan pola asuh ibu yang penuh waktu, sehingga pemberian makan dapat maksimal dilakukan dengan baik.

Tabel 2. Distribusi Status Gizi Anak Prasekolah berdasarkan TB/U di TK/RA Wilayah Keluarahan Karang Pule Kota mataram Tahun 2019

\begin{tabular}{|c|c|c|c|c|c|c|c|c|}
\hline \multirow{2}{*}{ Pekerjaan Ibu } & \multicolumn{9}{|c|}{$\begin{array}{c}\text { Status Gizi (TB/U) } \\
\text { kurang }\end{array}$} & \multicolumn{2}{|c|}{ Tinggi normal } & \multicolumn{2}{|c|}{ Tinggi Lebih } & \multicolumn{2}{|c|}{ Total } \\
\cline { 2 - 10 } & $\mathrm{n}$ & $\%$ & $\mathrm{~N}$ & $\%$ & $\mathrm{n}$ & $\%$ & $\mathrm{~N}$ & $\%$ \\
\hline IRT & 6 & 16 & 13 & 34 & 1 & 3 & 20 & 52 \\
\hline $\begin{array}{c}\text { Pedagang- } \\
\text { Wirausaha }\end{array}$ & 1 & 3 & 5 & 13 & 3 & 8 & 9 & 24 \\
\hline Pegawai & 2 & 5 & 7 & 18 & 0 & 0 & 9 & 24 \\
\hline Total & 9 & 24 & 25 & 66 & 4 & 11 & 38 & 100 \\
\hline
\end{tabular}

Sumber: data primer
Dari analisis uji Chi Square antara pekerjaan ibu dengan status gizi (TB/U) anak prasekolah, terdapat nilai $p=0.123$. Hal ini menunjukkan bahwa tidak ada hubungan antara pekerjaan orang tua dengan tinggi badan anak prasekolah RA Al-Fath. Pekerjaan orang tua berkaitan dengan pendapatan keluarga, dengan pendapatan yang memadai akan menunjang tumbuh kembang anak karena tercukupinya kebutuhan anak seperti makanan sehat. Namun, pekerjaan dan penghasilan orang tua yang tinggi bukanlah jaminan akan memiliki status gizi yang baik, karena masih ada beberapa faktor yang saling berkaitan seperti tingkat pendidikan dan pengetahuan orang tua tentang gizi yang baik, banyaknya jumlah anggota keluarga yang akan dinafkahi, jarak kelahiran yang terlalu dekat juga sangat mempengaruhi dalam pemberian ASI, dan pola pengasuhan (Andriana dan Wirjatmadi, 2016).

Penelitian yang dilakukan oleh Fabelina, Maureen dan Nancy (2016) juga menyatakan bahwa tidak ada hubungan Antara pekerjaan ibu dengan kejadian stunting pada anak balita di Kabupaten Minahasa Utara. Masih ada 24\% tinggi badan kurang pada anak prasekolah di RA Al-Fath dan $16 \%$ nya berasal dari anak yang memiliki ibu sebagai IRT. Tinggi badan kurang yang terus dibiarkan akan menjadi kasus stunting pada anak sekolah.

Menurut WHO (2006) dalam Yuliana dan Hakim (2019) diantara faktor yang dapat menyebabkan anak stunting adalah panjang badan lahir, status ekonomi keluarga, tingkat pendidikan, dan faktor genetik orang tua. Dikatakan bahwa, orang tua dengan dengan tinggi badan pendek memungkinkan akan mehasilkan bayi dengan panjangbadan pula, hal ini dikarenakan penurunan genetik oleh orang tua. Untuk dapat mendapatkan tinggi badan yang ideal maka harus 
dikejar saat masa pertumbuhan anak melalui asupan gizi yang memadai dan melindungi anak dari penyakit.

Hal ini sejalan dengan penelitian yang dilakukan oleh Amin dan Julia (2014) yang mengatakan bahwa variable pekerjaan tidak berhubungan dengan kejadian stunting (pendek/ tinggi kurang), tetapi variable tinggi badan ibu merupakan faktor risiko terjadinya stunting.

Ketiadaan hubungan pekerjaan dengan status gizi anak prasekolah baik secara IMT/U maupun TB/U dapat disebabkan karena beberapa hal yang menjadi keterbatasan dalam penelitian ini. Keterbatasan penelitian ini adalah jumlah sampel yang sedikit, dan munculnya faktor bias yang mempengaruhi status gizi balita yang tidak diukur yaitu tingkat pengetahuan dan pendidikan ibu.

\section{SIMPULAN DAN SARAN}

Kesimpulan penelitian ini adalah lebih dari $50 \%$ anak prasekolah di RA AlFath Kota Mataram memiliki status gizi yang normal dan tidak ada hubungan antara pekerjaan ibu dengan status gizi anak pra sekolah baik secara IMT maupun Tinggi badan $(p>0.05)$. Namun, masih ada lebih dari $20 \%$ anak prasekolah mengalami tinggi badan kurang. Selain itu, $45 \%$ dilihat dari IMT/u, status gizi anak berada dalam kategori status mal nutrisi. Mengingat masih adanya mal nutrisi pada anak pra sekolah baik menurut IMT/U maupun TB/U, maka perlu intervensi dari pihak tenaga kesehatan setempat untuk menanggulangi malnutrisi pada anak pra sekolah dan tidak hanya fokus pada peningkatan berat badan anak, melainkan juga membantu anak memiliki status gizi yang normal.

\section{DAFTAR PUSTAKA}

Adriani dan Wirjatmadi. 2012. Peranan Gizi dalam Siklus. Kehidupan. Jakarta : Kencana Prenada Media Group

Adriani, Merryana dan Wirjatmadi B. 2016. Pengantar Gizi Masyarakat. Jakarta:Kencana

Almatsier. 2012. Prinsip Ilmu Gizi. Jakarta : PT : Gramedia PustakaUtama

Amin, NurAfiadan Julia M. 2014. FaktorSosiodemografidanTinggiBad an Orang Tua serta Hubungannya dengan Kejadian Stunting padaBalitaUsia 6-23 Bulan. Jurnal Gizi dan Dietetik Indonesia. Diakses 28 April 2020.

Depkes RI. 2015. Situasi kesehatan anak balita di Indonesia. Pusdatin Kemenkes RI

Depkes RI. 2018. RISKESDAS 2018. Pusdatin Kemenkes RI

Fadillah, M. 2017. Buku Ajar Bermain dan Permainan anak usia dini. Jakarta

prenamediagruphttps://books.google .co.id/books?id=fja2DwAAQBAJ\& printsec $=$ frontcover $\& \mathrm{hl}=\mathrm{id} \# \mathrm{v}=$ onepa ge\&q\&f=false. Sitasi: 9 Oktober 2019

Hairunis, dkk. 2018. Hubungan Status Gizi dan Stimulasi Tumbuh Kembang dengan Perkembangan Balita.

https://saripediatri.org/index.php/sar i-pediatri/article/view/1405. Sitasi: 13 Juni 2019.

Handayani Reska. 2017. Faktor-Faktor Yang Berhubungan Dengan Status Gizi Pada Anak Balita .Journal Endurance 2(2) June 2017 (217224)

Kecamatan Sekarbela. 2018. Kecamatan Sekarbela dalam Data 2018. http://www.mataramkota.go.id/file/ Kecamatan\%20Sekarbela\%20Dala 
m\%20Data\%202018.pdf. Sitasi: 1 Juni 2019.

Kemenkes RI, 2015. Status Gizi Pengaruhi Kualitas Bangsa. http://www.depkes.go.id/article/prin t/15021300004/status-gizipengaruhi-kualitas-bangsa.html. Sitasi: 13 Juni 2019

Kemenkes RI. 2018. Apa saja bahaya Obesitas pada Anak. ?http://www.p2ptm.kemkes.go.id/in fographicp2ptm/obesitas/page/19/apa-sajabahaya-obesitas-pada-anak. Sitasi: 13 Oktober 2019

Kemenkes, 2018. Bersama Selesaikan Masalah Kesehatan. http://www.depkes.go.id/pdf.php?id $=18012900004$. Sitasi: 13 Oktober 2019

Kemenkes. 2018. $17,7 \%$ Balita Indonesia Masih Mengalami Masalah Gizi. https://databoks.katadata.co.id/da tapublish/2019/01/25/177-balitaindonesia-masih-mengalamimasalah-gizi. Sitasi: 20 Maret 2019.

Kontan. 2019. Inilah Aturan Baru Penerimaan Siswa Untuk TK, SD, SMP, SMA, dan SMK. https://nasional.kontan.co.id/news /inilah-aturan-baru-penerimaansiswa-untuk-tk-sd-smp-sma-dansmk?page=1. Sitasi: 20 Maret 2019

Nauw, Fabeliadkk. 2016. Hubungan

Antara

SosialEkonomidenganKejadian

Stunting padaBalita di

PulauMantehageKecamatanWori,

KabupatenMinahasa Utara.

Jurnalkesehatan. Di Akses di

http://medkesfkm.unsrat.ac.id/wpcontent/uploads/2016/11/JURNALFebelina-Nauw.pdf
Noordiati, 2018. Asuhan Kebidanan Neonatus, bayi, balita dan anak prasekolah. Malang : Wineka Media Novianto. 2019. Angka Stunting Turun, tapi Belum Standar WHO. https://beritagar.id/artikel/berita/angk a-stunting-turun-tapi-belum-standarwho. Diakses 20 April 2020.

Sa'diya. 2016. Hubungan Pola Makan Dengan Status Gizi Anak Pra Sekolah Di Paud Tunas Mulia Claket Kecamatan Pacet Mojokerto. Sitasi: 30 September 2019. http://ojs.umsida.ac.id/index.php/mi dwiferia/article/download/350/302

Soetjiningsih. 2008. Tumbuh Kembang Anak. Jakarta: EGC Kedokteran.

Supariasa dkk. 2016. Penilaian Status Gizi. Jakarta: Buku Kedokteran EGC.

UNICEF. 2019. Peringatan unicef : diet buruk merusak kesehatan anak di seluruh dunia. https://www.unicef.org/indonesia/id/ press-releases/peringatan-unicefdiet-buruk-merusak-kesehatan-anakdi-seluruh-dunia. Sitasi: 10 Oktober 2019

https://ejournal.almaata.ac.id/index.php/IJ ND/article/download/299/271

Yuliana, Wahidadan Hakim B.N. 2019. Darurat Stunting denganMelibatkanKeluarga. Sulsel :YayasanAhmarCendikia Indonesia 